\title{
3: $109281882-109244836$
}

National Cancer Institute

\section{Source}

National Cancer Institute. 3: 109281882-109244836. NCI Thesaurus. Code C41908.

Physical location of CD47_Gene 